\title{
Lead Isotopes to Identify Underwater Ceramic Contamination: The Example of the Kyrenia Shipwreck (Cyprus)
}

\author{
Virginie Renson * and Michael D. Glascock \\ Archaeometry Laboratory, Research Reactor Center, University of Missouri, 1513 Research Park Drive, \\ Columbia, MO 65211, USA; glascockm@missouri.edu \\ * Correspondence: rensonv@missouri.edu
}

check for updates

Citation: Renson, V.; Glascock, M.D. Lead Isotopes to Identify Underwater Ceramic Contamination: The Example of the Kyrenia Shipwreck (Cyprus). Minerals 2021, 11, 625. https://doi.org/10.3390/min11060625

Academic Editor: Mark Golitko

Received: 19 May 2021

Accepted: 10 June 2021

Published: 12 June 2021

Publisher's Note: MDPI stays neutral with regard to jurisdictional claims in published maps and institutional affiliations.

Copyright: (c) 2021 by the authors. Licensee MDPI, Basel, Switzerland. This article is an open access article distributed under the terms and conditions of the Creative Commons Attribution (CC BY) license (https:/ / creativecommons.org/licenses/by/ $4.0 /)$.
Abstract: We present the lead isotopic composition of ceramic fragments from the Kyrenia shipwreck (Cyprus), selected from three chemical groups related to the Rhodes and Alimos regions (Greece). Fragments of the lead sheathing covering the ship's hull and biogenic material formed on some of the ceramic sherds, were analyzed along with sherds from the Rhodes and Alimos source areas for comparison. The objective of this paper was to evaluate the impact of the seawater environment on the isotopic signature of the ceramics, and on our ability to use lead isotopes to source ceramics recovered from seawater. The results showed that the lead isotopic composition of the shipwreck ceramics was modified by its prolonged proximity to the lead hull sheathing. The lead signature of filtering marine organisms encrusted on the ceramics provided support for this hypothesis.

Keywords: lead isotopes; ceramics; shipwreck; seawater; weathering

\section{Introduction}

Since her discovery in 1967 off the northern coast of Cyprus (Figure 1), the Kyrenia shipwreck and her cargo have been subject of scientific studies focusing on questions related to the hull structure and carpentry techniques, repairs made to the ship over time, material used for her construction, the nature of her cargo, and her journey before she sank off the northern coast of Cyprus, 2200 years ago [1-6]. Over 400 amphorae and other ceramic wares including plates and cooking wares, were recovered during the excavations and subjected to multiple analyses, to identify their provenance and contribute to our understanding of the ship's journey [6].

The elemental chemistry of ceramics from the shipwreck was previously characterized by neutron activation analysis (NAA), with different approaches to data treatment necessary for assigning the ceramics to possible sources [7]. The examination of the NAA results and their comparison with reference groups of ceramics from multiple sources in the Mediterranean suggests at least 11 different provenances for the ceramics found on the shipwreck. In order to achieve this comparison, multiple elements had to be removed, as their concentrations were likely to have been affected by the interaction with seawater. Previous studies of ceramics recovered from underwater have demonstrated that the content in multiple elements can be depleted or enriched [8-12], which makes it difficult to apply this technique for the purpose of provenance, in this particular context.

Lead isotopic analyses have the ability to provide clues on both contamination and provenance of the material from the shipwreck. However, it is well-established that anthropic activities have modified the natural seawater lead isotopic signature and isotopic analyses have long been employed to identify the source of lead present in the marine environment [13-17]. Lead isotopes are also used as a tracer in archaeological science, where they allow tracing of the origin of artifacts by relating them to their geological raw material [18-22]. The recent application of isotopic analysis to archaeological ceramics from multiple contexts in the Eastern Mediterranean and Ancient Mexico, demonstrates that lead isotopes constitute a powerful analytical tool to both discriminate between ceramics of 
different origins and to relate ceramics to their source, either by comparison with ceramics of known origin or their raw materials [23,24].

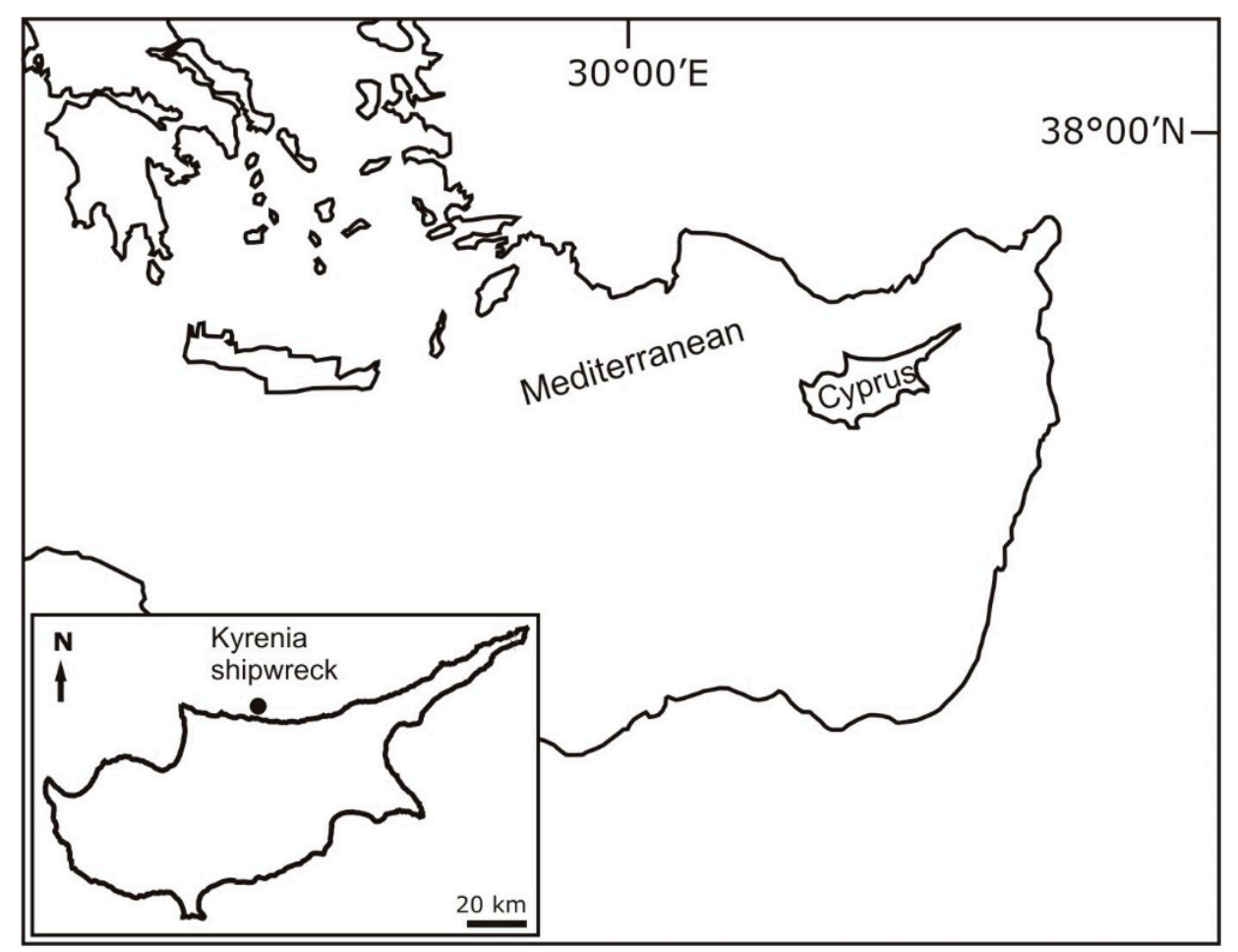

Figure 1. Map and location of the Kyrenia shipwreck.

In this study, we characterize the lead isotopic composition of ceramics recovered from a shipwreck to identify the source of the lead present in these artifacts. Other goals of the study include sourcing the ceramics from the Kyrenia shipwreck in particular, and examining the potential for lead isotopic analysis of ceramics from underwater contexts. For these purposes, lead isotopic analysis was conducted on-(1) ceramics from three different chemical groups assigned to different sources based on NAA, (2) ceramics of known provenance that were used to assign the provenance of some of the ceramics based on NAA, (3) fragments of the lead sheathing that was covering the hull of the ship, and (4) a calcium carbonate encrustation formed by marine organisms that developed on the ceramics.

\section{Materials and Methods}

\subsection{Material}

Thirteen ceramic fragments were selected for lead isotope analysis, from among three different chemical groups defined by the recent NAA results [7]. Using an analysis of the Euclidean distance search, the groups investigated here were proposed to be assigned based on elemental chemistry, respectively, to the Rhodes region (group 1, six sherds), to the Alimos, Athens, or Rhodes regions (group 2, five sherds), and to the Attic region (group 3, two sherds).

In addition, as reference groups, six sherds from Alimos and five from Rhodes were analyzed to characterize their lead isotopic composition. The ceramic sherds from Alimos analyzed here correspond to the Late Helladic period and were dated to approximately 1250-1100 BC. They are fragments of closed vessels, dipper, amphora, and stirrup jars that were excavated at Kontopigado. The ceramic sherds from Rhodes correspond to the Hellenistic period and were dated to approximately 400-100 BC. They are fragments of transport amphora and were excavated at Rhodes Town or Villanova. Two fragments of the lead sheathing that was protecting the hull of the ship were also analyzed. The application 
of lead sheathing to protect the hull from marine mollusks was common in the Roman period [25] and was employed to protect that of the Kyrenia ship [1]. Finally, one sample of the calcareous deposit formed by marine organisms (skeletons of Bryozoans, tubes of sea worms and conical shell of barnacles) present on some ceramic fragments, was characterized for both lead concentrations and lead isotopes.

\subsection{Sample Preparation}

\subsubsection{Ceramic Assemblage from the Shipwreck and from the Reference Sites}

The sherds from the Kyrenia shipwreck were cleaned mechanically using a microdrill equipped with a diamond bit, rinsed with ACS grade methanol and $\mathrm{mQ}$ water, and were allowed to dry at room temperature. A rapid surface chemical cleaning was then applied by immersing the fragments in $10 \mathrm{~mL}$ of $0.5 \mathrm{M} \mathrm{HNO}_{3}$ in a PFA Savillex ${ }^{\circledR}$ vial for a brief moment, rinsed with $\mathrm{mQ}$ water and immersed in $10 \mathrm{ml}$ of $\mathrm{mQ}$ water for deeper rinsing. Samples were dried at room temperature. The sherds from Rhodes and Alimos were cleaned mechanically using a micro drill equipped with a diamond bit, rinsed with PA methanol and $\mathrm{mQ}$ water, and were allowed to dry at room temperature. All dried sherds were then ground in an agate mortar. The powders were calcined at $550{ }^{\circ} \mathrm{C}$ and finally dried at $105^{\circ} \mathrm{C}$ for $24 \mathrm{~h}$. Around $250 \mathrm{mg}$ of powder was digested using $4 \mathrm{~mL} 24 \mathrm{HF}$, with $1 \mathrm{~mL} 14 \mathrm{~N} \mathrm{HNO}_{3}$ in microwave vessels $\left(190^{\circ} \mathrm{C}\right.$ for $\left.35 \mathrm{~min}\right)$ and evaporated at $90^{\circ} \mathrm{C}$. The residues were re-digested in $6 \mathrm{ml} 6 \mathrm{~N} \mathrm{HCl}$ and transferred to Savillex®vials that were placed on a hot plate at $125^{\circ} \mathrm{C}$ for $48 \mathrm{~h}$, and then evaporated at $90^{\circ} \mathrm{C}$.

\subsubsection{Marine Calcareous Deposit}

Some of the ceramics were covered by a composite calcareous deposit built by marine organisms. Small fragments of the deposit were carefully isolated from one ceramic (sherd P69). The organisms present on that specific sherd were identified as calcareous skeletons of Bryozoans, calcareous tubes of sea worms, and the calcareous conical shell of barnacles [26,27] (Mauro La Russa, pers. com.) (Figure 2). The isolated fragments were examined under a binocular microscope to ensure they were free from minerals/particles from the ceramic. They were then rinsed using $\mathrm{mQ}$ water, briefly cleaned using diluted Optima grade $\mathrm{HCl}$, rinsed with $\mathrm{mQ}$ water, and dried at $105^{\circ} \mathrm{C}$ for $24 \mathrm{~h}$. They were then gently ground in an agate mortar. The deposit was digested in $\mathrm{HNO}_{3}$, evaporated, re-dissolved in $6 \mathrm{~N} \mathrm{HCl}$, and evaporated at $90^{\circ} \mathrm{C}$.

\subsubsection{Lead Sheathing}

Two pieces of the lead sheathing identified as "AIF lead sheathing plotted $5 \mathrm{~B}$ " and "AHU lead sheathing plotted 6B" were analyzed. A fragment of each piece was isolated using a razor blade and carefully selected from areas that were not too weathered. The two fragments were scraped with the razor blade to mechanically remove as much of the surface deposit as possible. They were then rinsed with $\mathrm{mQ}$ water, PA methanol, $\mathrm{mQ}$ water, and leached using 5\% Optima Grade $\mathrm{HCl}$ for $10 \mathrm{~min}$, rinsed five times with $\mathrm{mQ}$ water and dried in the oven at $105^{\circ} \mathrm{C}$, for $24 \mathrm{~h}$. Two chips of $15-20 \mathrm{mg}$ were isolated from each fragment using a razor blade. Each chip was transferred in a tube for a deeper chemical cleaning cycle using $6 \mathrm{~N} \mathrm{HCl}$ Optima and with $\mathrm{mQ}$ water ( 2 times), followed by drying in the oven at $105{ }^{\circ} \mathrm{C}$. The four chips were then digested in $2 \mathrm{~mL} 6 \mathrm{~N} \mathrm{HCl}$ optima at $80^{\circ} \mathrm{C}$ for four days, using a graphite warming unit. An aliquot of each solution was taken to obtain approximately $2000 \mathrm{ng}$ of $\mathrm{Pb}$ and evaporated in Savillex ${ }^{\circledR v}$ vials at $90^{\circ} \mathrm{C}$. 


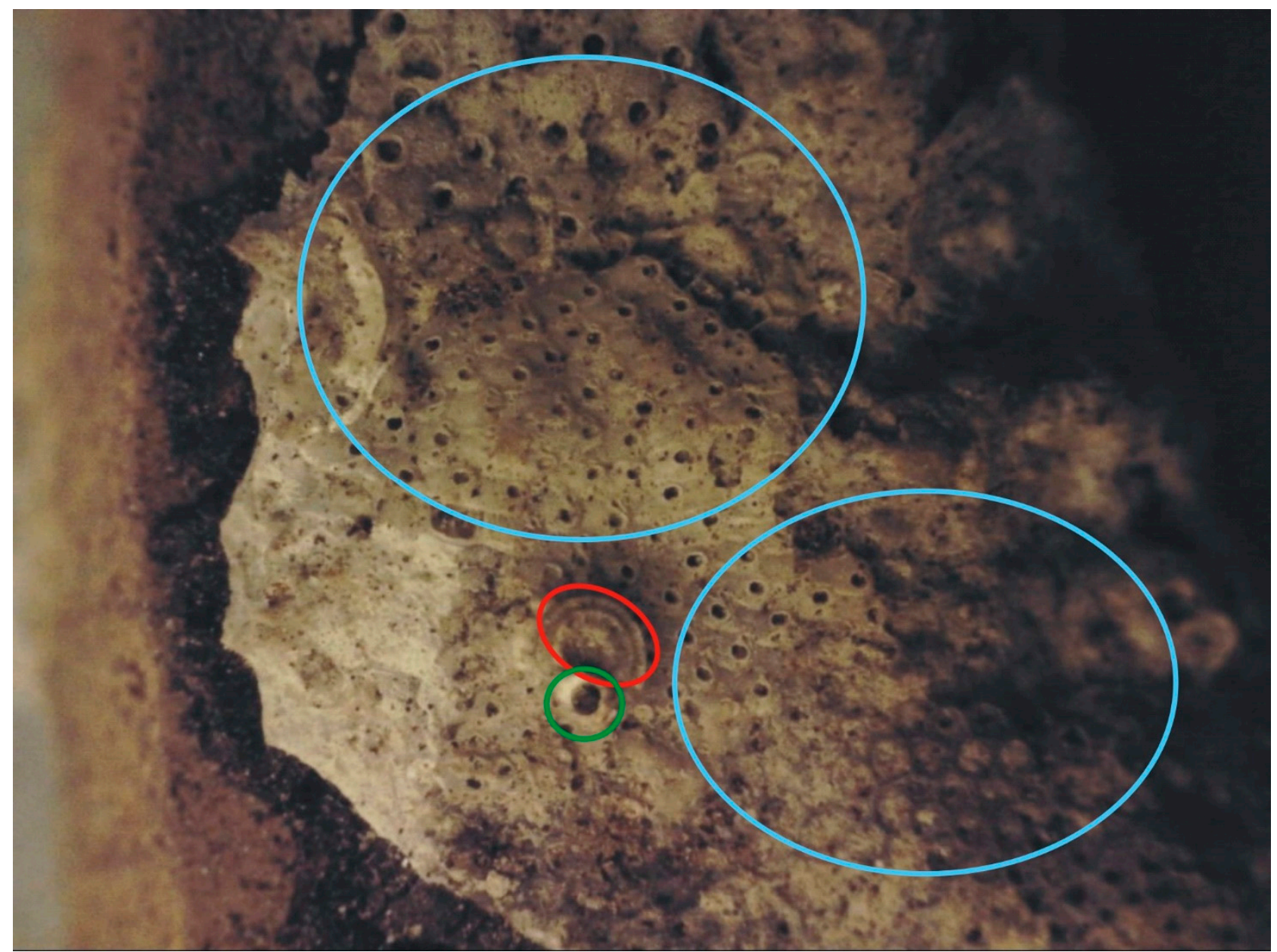

Figure 2. Example of marine organism shells developed on some Kyrenia ceramics. Circled in blue-zones with calcareous skeletons of Bryozoans, circled in red-calcareous tube of sea worm (Polychaetes), and circled in green-conical calcareous shell of Barnacle (Mauro La Russa, pers. com.) [26,27].

\subsection{Lead Isotope Analyses}

The dry residues of all samples (ceramics, marine organisms, and lead sheathing) were redigested in $2 \mathrm{~mL}$ of $\mathrm{HBr}$ and the lead was extracted using AG1-X8 resin loaded on polypropylene columns, using a protocol adapted from Weis et al. [28]. The Pb eluates were evaporated to dryness, the residues were re-digested in $14 \mathrm{~N} \mathrm{HNO}_{3}$, evaporated, and redissolved in $0.05 \mathrm{~N} \mathrm{HNO}_{3}$. Solutions were analyzed on the $\mathrm{Nu}$ Plasma II (Nu Instruments) multi collector-inductively coupled plasma-mass spectrometer, in operation at MURR. The SRM981 lead isotopic standard was analyzed multiple times at the beginning of each analytical session, and during analytical sessions after every two samples. Samples and standards were spiked with a Tl solution of the SRM997 and prepared to obtain approximately $250 \mathrm{ng} \mathrm{g}^{-1}$ of $\mathrm{Pb}$ and $62 \mathrm{ng} \mathrm{g}^{-1}$ in Tl. All values obtained for samples and standard were corrected for mass fractionation using the ${ }^{205} \mathrm{Tl} /{ }^{203} \mathrm{Tl}$ recommended value 2.38714 (NIST). Measurements were also corrected for isobaric interference of mercury at mass 204. Values obtained for the SRM981 were $36.699 \pm 0.009$ (2SD), $15.490 \pm 0.002$ (2SD), and $16.939 \pm 0.004$, for ${ }^{208} \mathrm{~Pb} /{ }^{204} \mathrm{~Pb},{ }^{207} \mathrm{~Pb} /{ }^{204} \mathrm{~Pb}$, and ${ }^{206} \mathrm{~Pb} /{ }^{204} \mathrm{~Pb}$, respectively. The ratios measured for the samples were finally corrected by standard bracketing [28,29], using the recommended values from Galer and Abouchami [30]. One duplicate (i.e., entire procedure applied twice to the same sample) and four replicates (i.e., repeated measurement of the same solution) were analyzed to evaluate the reproducibility of the method (Table 1). 


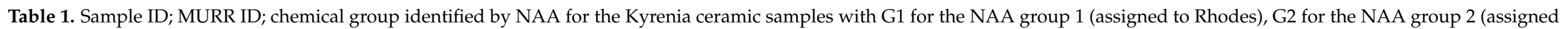

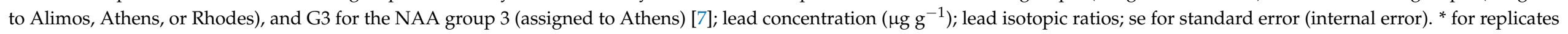
(i.e., second analysis of the same solution on the MC-ICP-MS), ${ }^{* *}$ for duplicates (i.e., entire procedure applied twice to the same sample).

\begin{tabular}{|c|c|c|c|c|c|c|c|c|c|c|c|c|c|c|}
\hline Sample ID & MURR ID & NAA group & {$[\mathrm{Pb}]$} & $1 /[\mathrm{Pb}]$ & ${ }^{208} \mathrm{~Pb} /{ }^{204} \mathrm{~Pb}$ & 2se & ${ }^{207} \mathrm{~Pb} /{ }^{204} \mathrm{~Pb}$ & 2 se & ${ }^{206} \mathrm{~Pb} /{ }^{204} \mathrm{~Pb}$ & 2se & ${ }^{208} \mathrm{~Pb} /{ }^{206} \mathrm{~Pb}$ & 2se & ${ }^{207} \mathrm{~Pb} /{ }^{206} \mathrm{~Pb}$ & $2 \mathrm{se}$ \\
\hline Alimos 11/22 & SHR222 & & & & 38.8825 & 0.0015 & 15.6729 & 0.0006 & 18.7362 & 0.0007 & 2.07527 & 0.00003 & 0.83650 & 0.00001 \\
\hline Alimos 11/26 & SHR226 & & & & 38.9397 & 0.0015 & 15.6835 & 0.0005 & 18.7531 & 0.0007 & 2.07644 & 0.00003 & 0.83631 & 0.00001 \\
\hline Alimos 11/31 & SHR231 & & & & 38.8898 & 0.0016 & 15.6776 & 0.0007 & 18.7462 & 0.0007 & 2.07455 & 0.00003 & 0.83630 & 0.00001 \\
\hline Alimos 11/36 & SHR236 & & & & 38.8922 & 0.0016 & 15.6752 & 0.0006 & 18.7532 & 0.0007 & 2.07387 & 0.00003 & 0.83586 & 0.00001 \\
\hline Alimos 11/112 & SHR312 & & & & 38.8809 & 0.0014 & 15.6733 & 0.0005 & 18.7456 & 0.0006 & 2.07413 & 0.00004 & 0.83611 & 0.00001 \\
\hline Alimos 11/117 & SHR317 & & & & 38.8845 & 0.0012 & 15.6734 & 0.0005 & 18.7383 & 0.0006 & 2.07515 & 0.00003 & 0.83644 & 0.00001 \\
\hline RHO 08/161 & RHO161 & & & & 38.8939 & 0.0015 & 15.6727 & 0.0005 & 18.7889 & 0.0006 & 2.07007 & 0.00003 & 0.83415 & 0.00001 \\
\hline RHO 08/218 & RHO218 & & & & 38.8892 & 0.0016 & 15.6753 & 0.0006 & 18.7990 & 0.0008 & 2.06868 & 0.00003 & 0.83383 & 0.00001 \\
\hline RHO 08/219 & RHO219 & & & & 38.8782 & 0.0016 & 15.6803 & 0.0006 & 18.8142 & 0.0006 & 2.06646 & 0.00003 & 0.83344 & 0.00001 \\
\hline RHO 08/077 & RHO077 & & & & 38.8370 & 0.0018 & 15.6714 & 0.0007 & 18.7412 & 0.0008 & 2.07228 & 0.00003 & 0.83620 & 0.00001 \\
\hline RHO 08/009 & RHO009 & & & & 38.8978 & 0.0026 & 15.6680 & 0.0006 & 18.7960 & 0.0008 & 2.06948 & 0.00005 & 0.83359 & 0.00002 \\
\hline Kyrenia Type I P38 & MUSW144 & G1 & 22.8 & 0.04 & 38.9243 & 0.0020 & 15.6809 & 0.0008 & 18.8712 & 0.0008 & 2.06259 & 0.00004 & 0.83093 & 0.00001 \\
\hline Kyrenia Type I P69 & & & 15.8 & 0.06 & 38.9544 & 0.0017 & 15.6828 & 0.0006 & 18.8877 & 0.0007 & 2.06241 & 0.00003 & 0.83032 & 0.00001 \\
\hline Kyrenia Type I P78 & MUSW131 & G1 & 20.2 & 0.05 & 38.9257 & 0.0016 & 15.6816 & 0.0006 & 18.8677 & 0.0006 & 2.06307 & 0.00003 & 0.83113 & 0.00001 \\
\hline Kyrenia Type I P115 & & & 13.7 & 0.07 & 38.9563 & 0.0023 & 15.6793 & 0.0008 & 18.8778 & 0.0006 & 2.06356 & 0.00003 & 0.83056 & 0.00001 \\
\hline Kyrenia Type I 529 & MUSW124 & G1 & 14.6 & 0.07 & 38.9466 & 0.0023 & 15.6832 & 0.0009 & 18.8871 & 0.0009 & 2.06210 & 0.00003 & 0.83037 & 0.00002 \\
\hline Kyrenia Type 2 P8 & MUSW022 & G2 & 52.0 & 0.02 & 38.8841 & 0.0021 & 15.6824 & 0.0009 & 18.8478 & 0.0009 & 2.06302 & 0.00002 & 0.83203 & 0.00001 \\
\hline Kyrenia Type 2 P13 & MUSW035 & G2 & 26.1 & 0.04 & 38.9239 & 0.0020 & 15.6812 & 0.0007 & 18.8543 & 0.0007 & 2.06444 & 0.00003 & 0.83169 & 0.00001 \\
\hline Kyrenia Type 2 P84 & MUSW023 & G2 & 151.8 & 0.01 & 38.8753 & 0.0012 & 15.6851 & 0.0005 & 18.8526 & 0.0005 & 2.06208 & 0.00003 & 0.83198 & 0.00002 \\
\hline Kyrenia Type 2 P95 & MUSW029 & G2 & 124.1 & 0.01 & 38.8683 & 0.0027 & 15.6832 & 0.0007 & 18.8359 & 0.0008 & 2.06350 & 0.00007 & 0.83262 & 0.00003 \\
\hline Kyrenia Type 2 P120 & MUSW037 & G2 & 28.6 & 0.03 & 38.9034 & 0.0015 & 15.6807 & 0.0006 & 18.8443 & 0.0006 & 2.06444 & 0.00002 & 0.83211 & 0.00001 \\
\hline Kyrenia Type 3 P19/29 & MUSW004 & G3 & 112.6 & 0.01 & 38.8791 & 0.0018 & 15.6845 & 0.0006 & 18.8577 & 0.0007 & 2.06172 & 0.00004 & 0.83173 & 0.00002 \\
\hline Kyrenia Type 3 P121 & MUSW010 & G3 & 26.7 & 0.04 & 38.9163 & 0.0014 & 15.6792 & 0.0006 & 18.7715 & 0.0007 & 2.07314 & 0.00003 & 0.83527 & 0.00001 \\
\hline Calcareous Organism & & & 217 & 0.005 & 38.8565 & 0.0015 & 15.6851 & 0.0006 & 18.8526 & 0.0006 & 2.06105 & 0.00003 & 0.83199 & 0.00001 \\
\hline
\end{tabular}


Table 1. Cont.

\begin{tabular}{|c|c|c|c|c|c|c|c|c|c|c|c|c|c|c|}
\hline Sample ID & MURR ID & NAA group & {$[\mathrm{Pb}]$} & $1 /[\mathrm{Pb}]$ & ${ }^{208} \mathrm{~Pb} /{ }^{204} \mathrm{~Pb}$ & $2 \mathrm{se}$ & ${ }^{207} \mathrm{~Pb} /{ }^{204} \mathrm{~Pb}$ & $2 \mathrm{se}$ & ${ }^{206} \mathrm{~Pb} /{ }^{204} \mathrm{~Pb}$ & 2se & ${ }^{208} \mathrm{~Pb} /{ }^{206} \mathrm{~Pb}$ & $2 \mathrm{se}$ & ${ }^{207} \mathrm{~Pb} /{ }^{206} \mathrm{~Pb}$ & 2se \\
\hline Lead Sheathing 5B Chip 1 & & & & & 38.8600 & 0.0017 & 15.6856 & 0.0006 & 18.8532 & 0.0006 & 2.06123 & 0.00003 & 0.83199 & 0.00001 \\
\hline Lead Sheathing 5B Chip 2 & & & & & 38.8623 & 0.0023 & 15.6871 & 0.0007 & 18.8562 & 0.0007 & 2.06104 & 0.00007 & 0.83195 & 0.00001 \\
\hline Lead Sheathing 6B Chip 1 & & & & & 38.8503 & 0.0022 & 15.6838 & 0.0006 & 18.8549 & 0.0010 & 2.06048 & 0.00006 & 0.83182 & 0.00002 \\
\hline Lead Sheathing 6B Chip 2 & & & & & 38.8725 & 0.0015 & 15.6891 & 0.0006 & 18.8570 & 0.0005 & 2.06150 & 0.00005 & 0.83202 & 0.00001 \\
\hline Alimos $11 / 22 *$ & & & & & 38.8875 & 0.0019 & 15.6728 & 0.0010 & 18.7365 & 0.0008 & 2.07542 & 0.00003 & 0.83649 & 0.00001 \\
\hline Kyrenia Type I P38 * & & & & & 38.9228 & 0.0019 & 15.6803 & 0.0006 & 18.8713 & 0.0007 & 2.06254 & 0.00004 & 0.83091 & 0.00002 \\
\hline Calcareous Organism * & & & & & 38.8520 & 0.0015 & 15.6845 & 0.0005 & 18.8537 & 0.0005 & 2.06074 & 0.00005 & 0.83191 & 0.00001 \\
\hline Kyrenia Type I P38 ** & & & & & 38.9265 & 0.0019 & 15.6813 & 0.0007 & 18.8760 & 0.0008 & 2.06220 & 0.00003 & 0.83074 & 0.00001 \\
\hline
\end{tabular}




\subsection{Elemental Analysis of the Ceramics}

A fraction of the parent solution prepared for isotopic analyses was aliquoted for elemental analysis. The $\mathrm{Pb}$ concentrations were measured in the Kyrenia ceramic sherds and the calcium carbonate deposit formed by marine organisms. The $\mathrm{Pb}$ concentrations were measured by ICP-MS using a PerkinElmer NexIon 300X operated in KED mode. Solutions were prepared in $3 \% \mathrm{HNO}_{3}$ and internal standards of Sc, In, and $\mathrm{Tl}$ were added to the samples. The detection limits were below $0.51 \mathrm{ng} \mathrm{Pb}$.

\section{Results}

\subsection{Kyrenia Samples}

Among the ceramic samples from the Kyrenia shipwreck, two groups and a singleton are identified, based on their lead isotopic composition (Figure 3 and Table 1).
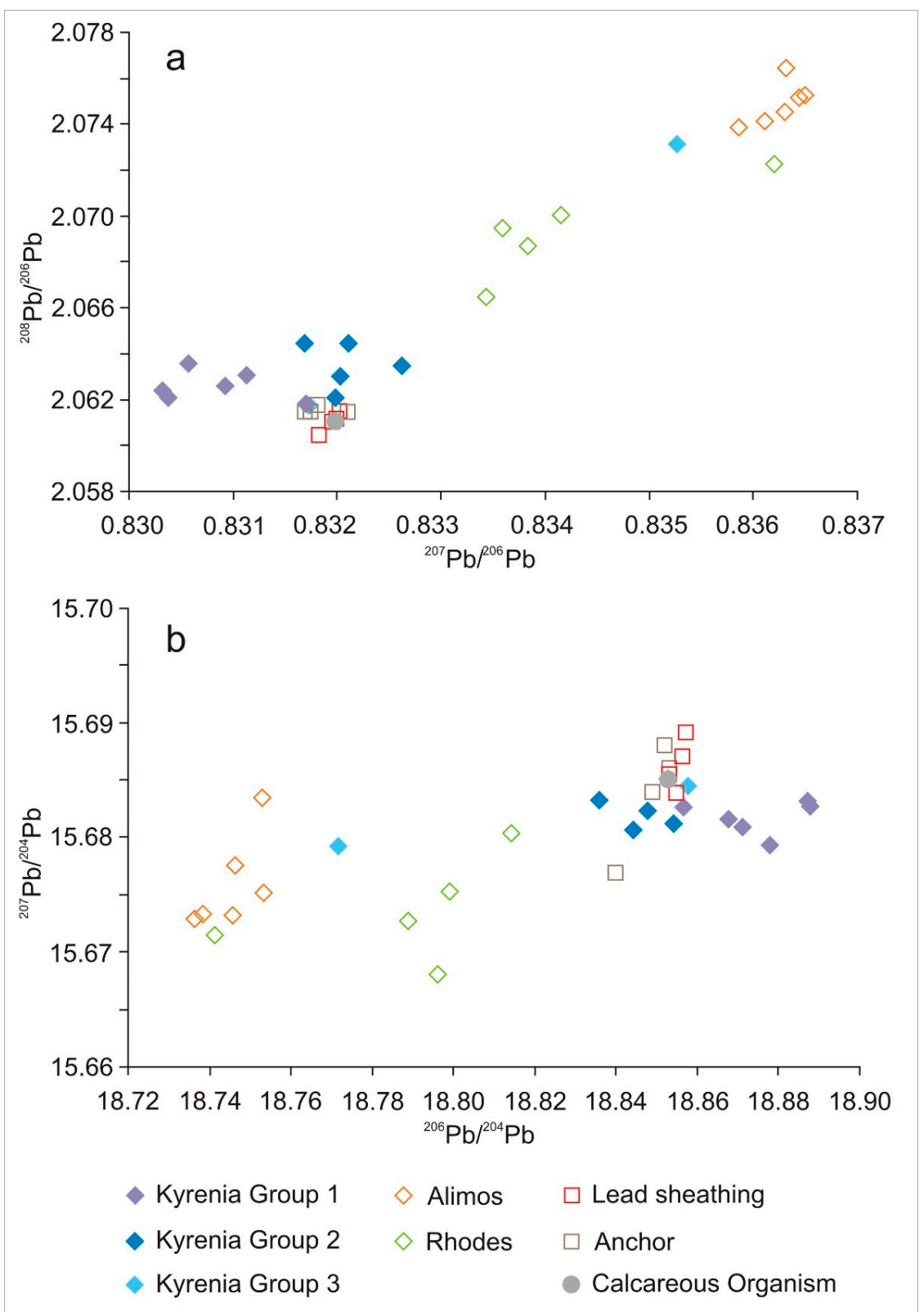

Figure 3. Three-isotope plots for the Kyrenia ceramics presented based on the chemical groups identified by NAA, ceramics from Rhodes and Alimos, the lead from the sheathing, and marine organism shells developed on the Kyrenia ceramics. The values for the anchor are from van Duivenvoorde [5]. (a) ${ }^{208} \mathrm{~Pb} /{ }^{206} \mathrm{~Pb}$ vs ${ }^{207} \mathrm{~Pb} /{ }^{206} \mathrm{~Pb}$, (b) ${ }^{207} \mathrm{~Pb} /{ }^{204} \mathrm{~Pb}$ vs ${ }^{206} \mathrm{~Pb} /{ }^{204} \mathrm{~Pb}$. 
One isotopic group is composed of seven samples including five samples of the NAA Group 2, one sample from NAA Group 1, and one sample from NAA Group 3. The lead isotopic composition of this assemblage varies between 15.6807 and 15.6851 , between 18.8359 and 18.8577 , between 2.06172 and 2.06444 , and between 0.83169 and 0.83262 , for ${ }^{207} \mathrm{~Pb} /{ }^{204} \mathrm{~Pb},{ }^{206} \mathrm{~Pb} /{ }^{204} \mathrm{~Pb},{ }^{208} \mathrm{~Pb} /{ }^{206} \mathrm{~Pb}$ and ${ }^{207} \mathrm{~Pb} /{ }^{206} \mathrm{~Pb}$ ratios, respectively (Figure 3 and Table 1). In the NAA Group 2 fragments, the lead concentration varies between $26.1 \mathrm{ppm}$ and $151.8 \mathrm{ppm}$, and it is $49.3 \mathrm{ppm}$ in the sample from Group 1 and $112.6 \mathrm{ppm}$ for the sample from Group 3 (Table 1).

A second isotopic group is composed of five samples from the NAA Group 1. The lead isotopic composition of this group varies between 15.6793 and 15.6832 , between 18.8677 and 18.8877, between 2.06210 and 2.06356 , and between 0.83032 and 0.83113 , for ${ }^{207} \mathrm{~Pb} /{ }^{204} \mathrm{~Pb}$, ${ }^{206} \mathrm{~Pb} /{ }^{204} \mathrm{~Pb},{ }^{208} \mathrm{~Pb} /{ }^{206} \mathrm{~Pb}$, and ${ }^{207} \mathrm{~Pb} /{ }^{206} \mathrm{~Pb}$ ratios, respectively (Figure 3 and Table 1 ). The lead concentration in the assemblage varies between $13.7 \mathrm{ppm}$ and $22.8 \mathrm{ppm}$ (Table 1).

The singleton from NAA Group 3 has a lead isotopic composition that presents the values of $15.6792,18.7715,2.07314$, and 0.83527 , for ${ }^{207} \mathrm{~Pb} /{ }^{204} \mathrm{~Pb},{ }^{206} \mathrm{~Pb} /{ }^{204} \mathrm{~Pb},{ }^{208} \mathrm{~Pb} /{ }^{206} \mathrm{~Pb}$, and ${ }^{207} \mathrm{~Pb} /{ }^{206} \mathrm{~Pb}$ ratios, respectively (Figure 3 and Table 1), and a lead concentration of 26.7 ppm (Table 1).

\subsection{Reference Ceramics from Rhodes and Alimos}

The ceramics from Rhodes and Alimos are separated in two groups. One is composed of four samples from Rhodes. The lead isotopic composition of this group varies between 15.6680 and 15.6803 , between 18.7889 and 18.8142, between 2.06646 and 2.07007, and between 0.83344 and 0.83415 , for ${ }^{207} \mathrm{~Pb} /{ }^{204} \mathrm{~Pb},{ }^{206} \mathrm{~Pb} /{ }^{204} \mathrm{~Pb},{ }^{208} \mathrm{~Pb} /{ }^{206} \mathrm{~Pb}$, and ${ }^{207} \mathrm{~Pb} /{ }^{206} \mathrm{~Pb}$ ratios, respectively (Figure 3 and Table 1). The second one is composed of the six samples from Alimos and one sample from Rhodes. The lead isotopic composition of this group varies between 15.6714 and 15.6835 , between 18.7362 and 18.7532 , between 2.07228 and 2.07644, and between 0.83586 and 0.83650 , for ${ }^{207} \mathrm{~Pb} /{ }^{204} \mathrm{~Pb},{ }^{206} \mathrm{~Pb} /{ }^{204} \mathrm{~Pb},{ }^{208} \mathrm{~Pb} /{ }^{206} \mathrm{~Pb}$, and ${ }^{207} \mathrm{~Pb} /{ }^{206} \mathrm{~Pb}$ ratios, respectively (Figure 3 and Table 1 ).

\subsection{Lead Sheathing and Calcium Carbonate Deposit}

The four lead sheathing samples and the calcareous deposit on the ceramics form a narrow group with a lead isotopic composition that varies between 15.6838 and 15.6891, between 18.8526 and 18.8570, between 2.06048 and 2.06150, and between 0.83182 and 0.83202 , for ${ }^{207} \mathrm{~Pb} /{ }^{204} \mathrm{~Pb},{ }^{206} \mathrm{~Pb} /{ }^{204} \mathrm{~Pb},{ }^{208} \mathrm{~Pb} /{ }^{206} \mathrm{~Pb}$, and ${ }^{207} \mathrm{~Pb} /{ }^{206} \mathrm{~Pb}$ ratios, respectively (Figure 3 and Table 1). The lead isotopic composition of the lead sheathing also corresponds with that of the lead used in the anchors of the shipwreck [5].

\section{Discussion}

Groups 1 and 2 have a very similar composition in ${ }^{207} \mathrm{~Pb} /{ }^{204} \mathrm{~Pb}$ and ${ }^{208} \mathrm{~Pb} /{ }^{206} \mathrm{~Pb}$, but Group 1 has more radiogenic values for ${ }^{206} \mathrm{~Pb} /{ }^{204} \mathrm{~Pb}$ and less radiogenic ones for ${ }^{207} \mathrm{~Pb} /{ }^{206} \mathrm{~Pb}$ ratio. The range of variation for each group is very small. The two samples from Group 3 present two distinct isotopic compositions.

The recent elemental chemistry results suggest that Group 1 has closest affinities with jars from Rhodes and Group 2 with ceramics from Alimos, Rhodes, or Attica [7]. When compared to the ceramic samples from Rhodes and Alimos analyzed here, none of the samples from Groups 1 and 2 has a lead isotopic composition compatible with the samples from these sources, with both groups from the shipwreck having more radiogenic ${ }^{206} \mathrm{~Pb} /{ }^{204} \mathrm{~Pb}$ and less radiogenic ${ }^{208} \mathrm{~Pb} /{ }^{206} \mathrm{~Pb}$ and ${ }^{207} \mathrm{~Pb} /{ }^{206} \mathrm{~Pb}$ values. Based on elemental chemistry, Group 3 has the closest affinities with Attica. One of the samples from Group 3 has an isotopic signature compatible with that of the material from Alimos. However, the second sample does not have a compatible signature, instead has one that overlaps with samples from Group 2. In terms of provenance, these results do not allow an association with Rhodes over Alimos. The absence of compatibility between Group 1 and the few samples from Rhodes do not, however, exclude the island as a source. At this stage, only 
one type of Rhodian jar is used for comparison and likely does not represent the diversity of clays available on the island. The geology of Rhodes is composed of sedimentary rocks, including limestones and flysch (some of which underwent some degree of metamorphism) of different geological age, deposits of lacustrine origins, and the occurrence of ophiolite and diverse quaternary sediments [31], which are likely to provide clays with diverse lead isotopic composition. The samples used here to represent the ceramic production in Rhodes are therefore limited and the analysis of representative clay sources from the island would be necessary to confirm a possible Rhodian origin using lead isotopes. The compatibility between the Rhodes samples and the ceramics from Group 1 are observed, however, based on the elemental chemistry.

The discrepancy between the findings of the elemental analysis and the lead isotopes may be the result of a modification of the isotopic composition of the ceramics. The lead isotopic composition of the samples from Group 2 overlaps with that of the isotopic composition of the lead sheathing, the anchor, and the shells from the marine organisms, but is also compatible with a mixing between the composition of Alimos/Rhodes ceramics and the lead from the sheathing. One sample from Group 1 has a composition similar to that of the sheathing. The other samples from this group, however, do not have a signature that overlaps with that of the sheathing, and their signature is also incompatible with that of a mixing that would result from Alimos/Rhodes as one of the end-members and the lead from the sheathing as the second end-member. For Group 3, the sample that presents the highest lead concentration (sample P19/29, $112.6 \mu \mathrm{g} \mathrm{g}^{-1}$ ) has the exact same signature as the lead sheathing, for all ratios. The other sample (sample P121) has a lead isotopic composition that is close to that of the Alimos samples. The lead concentration within a single group is variable (especially in Group 2 and Group 3), which could indicate an enrichment in lead, due to a contamination of the ceramics while underwater. This possibility is further investigated by examining how the isotopic composition varies in relation to the $\mathrm{Pb}$ concentration (Figure 4). The plot presenting the isotopic composition vs. $1 /[\mathrm{Pb}]$ shows that in Group 1, the ${ }^{208} \mathrm{~Pb} /{ }^{204} \mathrm{~Pb}$ and ${ }^{206} \mathrm{~Pb} /{ }^{204} \mathrm{~Pb}$ values are less radiogenic when the $\mathrm{Pb}$ concentration increases but no effect is observed on ${ }^{207} \mathrm{~Pb} /{ }^{204} \mathrm{~Pb}$ (Figure 4). In Group 2, when the $\mathrm{Pb}$ concentration increases, the ${ }^{208} \mathrm{~Pb} /{ }^{204} \mathrm{~Pb}$ values are less radiogenic and the ${ }^{207} \mathrm{~Pb} /{ }^{204} \mathrm{~Pb}$ values are more radiogenic, but no effect is observed on the ${ }^{206} \mathrm{~Pb} /{ }^{204} \mathrm{~Pb}$ ratio (Figure 4). In Group 3, the sample presenting high lead concentration $\left(112.6 \mu \mathrm{g} \mathrm{g}^{-1}\right)$ has a less radiogenic ${ }^{208} \mathrm{~Pb} /{ }^{204} \mathrm{~Pb}$ value and more radiogenic ${ }^{207} \mathrm{~Pb} /{ }^{204} \mathrm{~Pb}$ and ${ }^{206} \mathrm{~Pb} /{ }^{204} \mathrm{~Pb}$ values than the sample presenting lower $\mathrm{Pb}$ concentration $\left(26.7 \mu \mathrm{g} \mathrm{g}^{-1}\right)$ (Figure 4$)$. In all three groups, when an increase in lead content correlates with a variation in the isotopic ratio, the ratios shift towards the lead isotopic composition of the lead from the sheathing, which is also that of the shells of the marine organisms that encrusted the ceramics. The combination of the lead concentrations to that of the lead isotopic ratios observed here is compatible with a contamination of the body of some ceramics by lead from the sheathing.

A recent study conducted on seawater columns surrounding a modern shipwreck showed evidence of contamination of the seawater dissolved and particulate phases, by the metals originating from the ship's hull weathering [32]. In this study, the authors demonstrated that the lead concentrations in the seawater increased from the top to the bottom of the water column, and were also higher downstream from the shipwreck [32]. Similarly, we propose that water in close proximity to the shipwreck may have weathered the lead sheathing, increasing the content of this element in both the dissolved and particulate fraction of the seawater.

Lead in seawater is mainly present in the dissolved fraction where it preferentially bonds with organic ligands. In the inorganic complexes, lead is mainly present as $\mathrm{PbCO}_{3}$ or chlorides [33-35]. Lead present in the dissolved fraction of seawater can be incorporated in the tissues and shells of the filtering marine organisms that act as bio-accumulators. Numerous studies have used mussels as bio-indicators to monitor pollution related to modern human activities [36-42]. Barnacles, or Bryozoans, such as those developed on the ceramics from the shipwreck, also accumulate metals in the bio-mineralizations they produce [43]. 
The sample of calcium carbonate encrustations formed by marine organisms analyzed here presented a lead concentration of $217 \mu \mathrm{g} \mathrm{g}^{-1}$. This concentration was abnormally high and above the concentrations reported in the tissues and shells, in modern contexts [36,41,43-46]. This likely results from a lead accumulation by the organisms that developed on the surface of the ceramics, over time, and attests for a contamination of the surrounding seawater by the lead from the sheathing. The presence of bio-colonization and bio-mineralization on underwater artifacts can lead to their alteration [47]. An evaluation of the possible impact of these encrustations on the chemical alteration of the ceramics should also be examined. In the present case, the fragment of encrustation was sampled on a ceramic presenting lower lead concentration, which does not indicate an impact of the encrustations at this point.
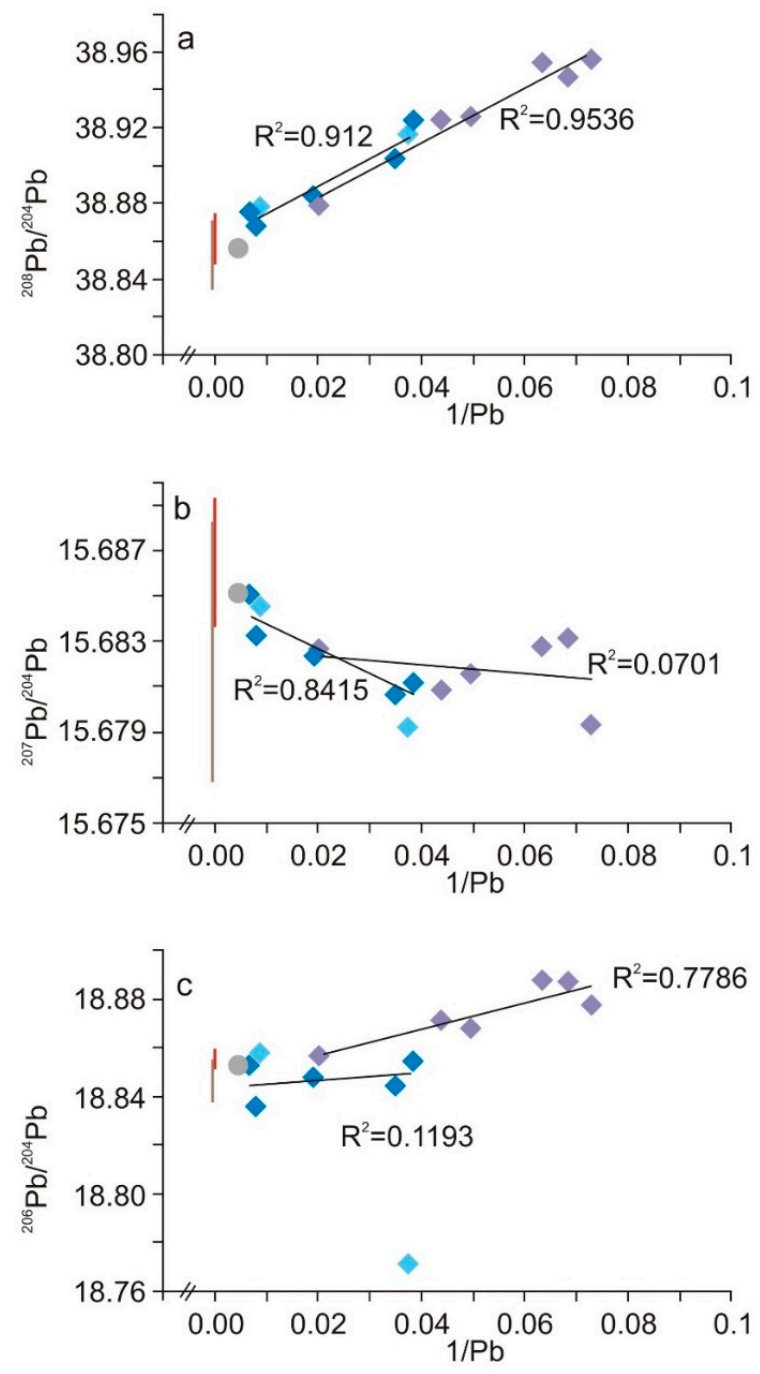

Figure 4. Lead isotopic composition vs. lead concentration. (a) ${ }^{208} \mathrm{~Pb} /{ }^{204} \mathrm{~Pb}$ vs. $1 /[\mathrm{Pb}]\left(\mu \mathrm{g} \mathrm{g}{ }^{-1}\right)$, (b) ${ }^{207} \mathrm{~Pb} /{ }^{204} \mathrm{~Pb}$ vs $1 /[\mathrm{Pb}]\left(\mu \mathrm{g} \mathrm{g}{ }^{-1}\right)$, and $(\mathbf{c}){ }^{206} \mathrm{~Pb} /{ }^{204} \mathrm{~Pb}$ vs $1 /[\mathrm{Pb}]\left(\mu \mathrm{g} \mathrm{g}{ }^{-1}\right)$. Note: The concentrations are reported as $1 /[\mathrm{Pb}]\left(\mu \mathrm{g} \mathrm{g}^{-1}\right)$, so higher concentrations are on the left-side of the $\mathrm{x}$-axis. The red vertical trait symbolizes the lead isotopic composition of the lead sheathing, the light-brown vertical trait symbolizes the lead isotopic composition of the anchor (values reported from van Duivenvoorde [5]). The other symbols are similar to the symbols used in Figure 3. 
The results of this first characterization of the lead isotopic signature of underwater ceramics demonstrates the need to consider multiple factors that can affect the original signature of clay-based artifacts in marine contexts. The signature of all potential contributing lead sources, including the duration of the stay underwater, alteration, and biogenic processes, may influence the resulting isotopic composition of the ceramic. This could affect the efficiency of this tool to source clay-based artifacts in this environment and the approach deserves further investigation. This includes characterization of the conditions of burial (presence of sediments to cover the ceramics); development and application of a leaching protocol to eliminate $\mathrm{Pb}$ related to post-immersion contamination, as applied to underwater rocks [48]; characterization of the potential clay source or further ceramic types from the potential sources; and examination of the potential impact of biogenic encrustations on the surface of objects, on their chemical composition.

\section{Conclusions}

This first study of lead isotopic composition of underwater archaeological ceramics from the Kyrenia shipwreck reveals a contamination of the assemblage by lead present in the environment. The evidence supports the lead sheathing that was covering the hull as this source. The proximity of the sheathing to the analyzed materials and their prolonged underwater context (23 centuries) were likely the two main factors that influenced the contamination. This was supported by the lead content and signature of the filtering organisms that accumulated the lead present in the surrounding seawater in their tissues and shells, formed encrustations on the ceramics, and also showed the impact of the lead from the sheathing. At least one ceramic did not show the same signs of alteration.

More broadly, this study demonstrates that the application of lead isotopic analysis to underwater ceramics is promising, pending the characterization of surrounding lead sources and weathering processes that might affect any particular clay-based artifacts.

Further assessment of the usefulness of lead isotope analysis for sourcing ceramics that have been long submerged in seawater is needed. The use of a leaching procedure and the isotopic and elemental characterization of both the leachate and the leached ceramic would be an essential next step. The possible contribution of the development of marine organism shells to the alteration of the chemical signature of clay-based artifacts also deserves examination. In the specific context of the Kyrenia shipwreck, further isotopic characterization of ceramics of known production or raw material would be a useful second phase in this research, as well as a microstructural analysis of the ceramic body of the potsherds. Due to the anthropic impact on the lead cycle and the presence of lead in marine contexts, another critical step in similar contexts would be the characterization of the seawater isotopic composition, either by analyzing the water body in proximity of a shipwreck or that of marine organism encrustations that have developed on the archaeological material or in the vicinity of the material.

Author Contributions: Conceptualization, V.R. and M.D.G.; methodology, V.R. and M.D.G.; formal analysis, V.R.; investigation, V.R.; resources, V.R. and M.D.G.; writing-original draft preparation, V.R.; writing-review and editing, V.R. and M.D.G.; visualization, V.R. All authors have read and agreed to the published version of the manuscript.

Funding: The Nu Plasma II acquisition was funded by the NATIONAL SCIENCE FOUNDATION (grant BCS-0922374). The Archaeometry Laboratory at MURR is supported by the NATIONAL SCIENCE FOUNDATION (grant BCS-1912776). V.R. was partly supported by a postdoctoral fellowship of the BELGIAN AMERICAN EDUCATIONAL FOUNDATION.

Data Availability Statement: All data supporting the reported results are presented in Table 1.

Acknowledgments: We warmly thank Susan Katzev for providing the ceramics and the lead fragments of the sheathing. We thank Vassilis Kilikoglou from the National Center for Scientific Studies "Demokritos" for providing ceramic samples from Alimos and Rhodes. We thank Jeffrey Alvey and Francois De Vleeschouwer for their constructive comments on a previous version of the manuscript. We thank the editor and two anonymous reviewers who helped improving the manuscript. 
Conflicts of Interest: The authors declare no conflict of interest.

\section{References}

1. Katzev, M.L. The Kyrenia Shipwreck. Exped. Mag. 1969, 11, 55-59.

2. Katzev, M.L. The reconstruction of the Kyrenia ship, 1972-1975. Natl. Geogr. Soc. Res. Rep. 1981, 13, $315-328$.

3. Steffy, J.R. The Kyrenia ship: An interim report on its hull construction. Am. J. Archaeol. 1985, 89, 71-101. [CrossRef]

4. Katzev, S.W. Resurrecting an Ancient Greek Ship: Kyrenia, Cyprus. In Beneath the Seven Seas; Bass, G.F., Ed.; Thames and Hudson: New York, NY; London, UK, 2005; pp. 72-79.

5. van Duivenvoorde, W. The anchor of the 3rd-Century-BC ship from Kyrenia, Cyprus: A one-armed wooden anchor with a lead-filled stock. Int. J. Naut. Archaeol. 2012, 41, 397-407. [CrossRef]

6. Katzev, S.W.; Swiny, L.M. The Kyrenia Ship Final Excavation Report. Volume I: History of Excavation, Amphoras, Pottery and Coins as Evidence for Dating; Oxbow Books: Havertown, PA, USA, 2021; p. 464.

7. Glascock, M.D.; Cecil, L.G. Investigating the provenance of ceramics from the Kyrenia ship with neutron activation analysis. In The Kyrenia Ship Final Excavation Report. Volume II; Katzev, S.W., Swiny, L.W., Eds.; Oxbow Books: Havertown, PA, USA; p. 464, in press.

8. Bearat, H.; Dufournier, D.; Nouet, Y. Alterations of ceramics due to contact with seawater. Archaeol. Pol. 1992, $30,151-162$.

9. Pradell, T.; Vendrell-Saz, M.; Krumbein, W.; Picon, M. Altérations de céramiques en milieu marin: Les amphore de l'épave romaine. Rev. Archéométrie 1996, 20, 47-56. [CrossRef]

10. Montana, G.; Randazzo, L.; Belfiore, C.M.; La Russa, M.F.; Ruffolo, S.A.; De Francesco, A.M.; Pezzino, A.; Punturo, R.; Di Stefano, $\mathrm{V}$. An original experimental approach to study the alteration and/or contamination of archaeological ceramics originated by seawater burial. Period. Mineral. 2014, 83, 89-120. [CrossRef]

11. Iñañez, J.G.; Bettencourt, J.; Pinto Coelho, I.; Teixeira, A.; Arana, G.; Castro, K.; Sanchez-Garmendia, U. Hit and sunk: Provenance and alterations of ceramics from seventeenth century Angra D shipwreck. Archaeol. Anthropol. Sci. 2020, 12, 1-16. [CrossRef]

12. Maritan, L. Ceramic abandonment. How to recognise post-depositional transformations. Archaeol. Anthropol. Sci. 2020, 12, 1-20. [CrossRef]

13. Patterson, C.; Settle, D.; Glover, B. Analysis of lead in polluted coastal seawater. Mar. Chem. 1976, 4, 305-319. [CrossRef]

14. Patterson, C. Global pollution measured by lead in mid-ocean sediments. Nature 1987, 326, 244-245. [CrossRef]

15. Véron, A.; Lambert, C.E.; Isley, A.; Linet, P.; Grousset, F. Evidence of recent lead pollution in deep north-east Atlantic sediments. Nature 1987, 326, 278-281. [CrossRef]

16. Véron, A.; Church, T.M.; Flegal, A.R.; Patterson, C.C.; Erel, Y. Response of lead cycling in the surface Sargasso Sea to changes in tropospheric input. J. Geophys. Res. 1993, 98, 18269-18276. [CrossRef]

17. Hamelin, B.; Ferrand, J.L.; Alleman, L.; Nicolas, E.; Véron, A. Isotopic evidence of pollutant lead transport from North America to the subtropical North Atlantic gyre. Geochim. Cosmochim. Acta 1997, 61, 4423-4428. [CrossRef]

18. Farquhar, R.M.; Fletcher, I.R. Lead isotope identification of sources of galena from some Prehistoric Indian sites in Ontario, Canada. Science 1980, 207, 640-643. [CrossRef] [PubMed]

19. Gale, N.H.; Stos-Gale, Z.A. Bronze Age copper sources in the Mediterranean: A new approach. Science 1982, 216, 11-19. [CrossRef]

20. Degryse, P. Archeometric applications. In Isotopic Analysis-Fundamentals and Applications Using ICP-MS; Vanhaecke, F., Degryse, P., Eds.; Wiley-VCH: Weinheim, Germany, 2012; pp. 373-390.

21. Renson, V.; Jacobs, A.; Coenaerts, J.; Mattielli, N.; Nys, K.; Claeys, P. Using lead isotopes to determine pottery provenance in Cyprus: Clay source Signatures and comparison with Late Bronze Age Cypriote pottery. Geoarchaeology 2013, 28, 517-530. [CrossRef]

22. Stephens, J.; Killick, D.; Wilmsen, E.; Denbow, J.; Miller, D. Lead isotopes link copper artefacts from northwestern Botswana to the Copperbelt of Katanga Province, Congo. J. Archaeol. Sci. 2020, 117, 105124. [CrossRef]

23. Renson, V.; Martínez-Cortizas, A.; Mattielli, N.; Coenaerts, J.; Sauvage, C.; De Vleeschouwer, F.; Lorre, C.; Vanhaecke, F.; Bindler, R.; Rautman, M.; et al. Lead isotopic analysis within a multi-proxi approach to trace pottery sources. The example of White Slip II sherds from Late Bronze Age sites in Cyprus and Syria. Appl. Geochem. 2013, 28, 220-234. [CrossRef]

24. Renson, V.; Neff, H.; Martinez-Cortizas, A.; Blomster, J.P.; Cheetham, D.; Glascock, M.D. Lead and strontium isotopes as tracers for Early Formative pottery exchange in ancient Mexico. J. Archaeol. Sci. 2021, 126, 105307. [CrossRef]

25. Kahanov, Y.; Ashkenazi, D. Lead sheathing of ship hulls in the Roman period: Archaeometallurgical characterization. Mater. Charact. 2011, 62, 768-774. [CrossRef]

26. La Russa, M.F.; Ruffolo, S.A.; Ricca, M.; Ricci, S.; Davidde, B.; Barca, D.; Capristo, V. A multidisciplinary approach to the study of underwater artifacts: The case of a Tritone Barbato marble statue (Grotta Azzurra, Island of Capri, Naples). Period. Mineral. 2013, 82, 101-111. [CrossRef]

27. Aloise, P.; Ricca, M.; La Russa, M.F.; Ruffolo, S.A.; Belfiore, C.M.; Padeletti, G.; Crisci, G.M. Diagnostic analysis of stone materials from underwater excavations: The case study of Roman archaeological site of Baia (Naples, Italy). Appl. Phys. A 2014, 114, 655-662. [CrossRef]

28. Weis, D.; Kieffer, B.; Maerschalk, C.; Barling, J.; de Jong, J.; Williams, G.A.; Hanano, D.; Pretorius, W.; Mattielli, N.; Scoates, J.S.; et al. High-precision isotopic characterization of USGS reference materials by TIMS and MC-ICP-MS. Geochem. Geophys. Geosystems 2006, 7, Q08006. [CrossRef] 
29. White, W.M.; Albarède, F.; Télouk, P. High-precision analysis of Pb isotope ratios by multi-collector ICP-MS. Chem. Geol. 2000, 167, 257-270. [CrossRef]

30. Galer, S.J.G.; Abouchami, W. Practical applications of lead triple spiking correction of instrumental mass discrimination. Mineral. Mag. 1998, 62A, 491-492. [CrossRef]

31. Tsombos, P.I.; Nikolakopoulos, K.G.; Photiades, A.; Psonis, K. Updating the 1:50.000 geological maps of Rhodes island using remote sensing data and GIS techniques. In Proceedings of the SPIE 6749, Remote Sensing for Environmental Monitoring, GIS Applications, and Geology VII, 67491H, Florence, Italy, 29 October 2007. [CrossRef]

32. Annibaldi, A.; Illuminati, S.; Truzzi, C.; Scarponi, G. SWASV speciation of $\mathrm{Cd}, \mathrm{Pb}$ and $\mathrm{Cu}$ for the determination of seawater contamination in the area of the Nicole shipwreck (Ancona coast, Central Adriatic Sea). Mar. Pollut. Bull. 2011, 62, 2813-2821. [CrossRef] [PubMed]

33. Byrne, R.H. Inorganic lead complexation in natural seawater determined by UV spectroscopy. Nature 1981, 290, 487-489. [CrossRef]

34. Byrne, R.H. Inorganic speciation of dissolved elements in seawater: The influence of $\mathrm{pH}$ on concentration ratios. Geochem. Trans. 2002, 3, 11-16. [CrossRef]

35. Reuer, M.; Weiss, D. Anthropogenic lead dynamics in the terrestrial and marine environment. Phil. Trans. R. Soc. Lond. A 2002, 360, 2889-2904. [CrossRef]

36. Chow, T.J.; Snyder, H.G.; Snyder, C.B. Mussels (Mytilus sp.) as an indicator of lead pollution. Sci. Total Environ. 1976, 6, 55-63. [CrossRef]

37. Sturesson, U. Lead enrichment in shells of Mytilus edulis. Ambio 1976, 5, 253-256.

38. Pitts, L.C.; Wallace, G.T. Lead deposition in the shell of the bivalve Mya arenaria: An indicator of dissolved lead in seawater. Estuar. Coast Shelf Sci. 1994, 39, 93-104. [CrossRef]

39. Boisson, F.; Cotret, O.; Fowler, S.W. Bioaccumulation and retention of lead in the mussel Mytilus galloprovincialis following uptake from seawater. Sci. Total Environ. 1998, 222, 55-61. [CrossRef]

40. Labonne, M.; Ben Othman, D.; Luck, J.-M. Recent and past anthropogenic impact on a Mediterranean lagoon: Lead isotope constraints from mussel shells. Appl. Geochem. 1998, 13, 885-892. [CrossRef]

41. Shiel, A.E.; Weis, D.; Orians, K.J. Tracing cadmium, zinc and lead sources in bivalves from the coasts of western Canada and the USA using isotopes. Geochim. Cosmochim. Acta 2012, 76, 175-190. [CrossRef]

42. Steinhardt, J.; Butler, P.G.; Carroll, M.L.; Hartley, J. The application of long lived bivalve sclerochronology in environmental baseline monitoring. Front. Mar. Sci. 2016, 3, 176. [CrossRef]

43. Amoozadeh, E.; Malek, M.; Rashidinejad, R.; Nabavi, S.; Karbassi, M.; Ghayoumi, R.; Ghorbanzadeh Zafarani, G.; Salehi, H.; Sures, B. Marine organisms as heavy metal bioindicators in the Persian Gulf and the Gulf of Oman. Environ. Sci. Pollut. Res. 2014, 21, 2386-2395. [CrossRef]

44. Soto-Jiménez, M.F.; Páez-Osuna, F.; Scelfo, G.; Hibdon, S.; Franks, R.; Aggarawl, J.; Flegal, A.R. Lead pollution in subtropical ecosystems on the SE Gulf of California Coast: A study of concentrations and isotopic composition. Mar. Environ. Res. 2008, 66, 451-458. [CrossRef]

45. Jara-Marini, M.E.; Soto-Jiménez, M.F.; Páez-Osuna, F. Trophic relationships and transference of cadmium, copper, lead and zinc in a subtropical coastal lagoon food web from SE Gulf of California. Chemosphere 2009, 77, 1366-1373. [CrossRef]

46. El-Sorogy, A.S.; Attiah, A. Assessment of metal contamination in coastal sediments, seawaters and bivalves of the Mediterranean Sea coast, Egypt. Mar. Pollut. Bull. 2015, 101, 867-871. [CrossRef] [PubMed]

47. Cámara, B.; Álvarez de Buergo, M.; Bethencourt, M.; Fernández-Montblanc, T.; La Russa, M.F.; Ricca, M.; Fort, R. Biodeterioration of marble in an underwater environment. Sci. Total Environ. 2017, 609, 109-122. [CrossRef] [PubMed]

48. Hanano, D.; Scoates, J.S.; Weis, D. Alteration mineralogy and the effect of acid-leaching on the Pb-isotope systematics of ocean-island basalts. Am. Mineral. 2009, 94, 17-26. [CrossRef] 